\title{
Synthesis of Trifluoromethylated Pyrrolidine and Piperidine Amino Acids
}

trifluoromethylpyrrolidinecarboxylic acids<smiles>C=C(CC(NS(C)(C)C(C)(C)C)C(F)(F)F)C(=O)OCC</smiles><smiles>COC(=O)C(=O)OC1CCCC1</smiles><smiles>CCOC(=O)C1C[C@H](C(C)(C)C)N([Si](C)(O)C(C)(C)C)C1</smiles><smiles>O=C(O)[C@H]1C[C@@H](C(F)(F)F)CN1C(=O)O</smiles>

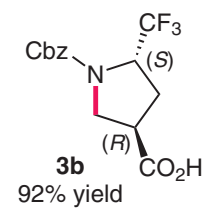<smiles>[R]C(=C)CN(C([R])C(=C)C)C(C)(F)S(=O)(=O)C(C)(C)C</smiles>

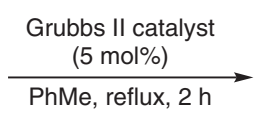<smiles>[R]C1=C([R])C([R])[C@@H](C(F)(F)F)N(S(=O)(=O)C(C)(C)C)C1</smiles>
5 $87-65 \%$ yield<smiles>CCOC1=CCN(S(=O)(=O)C(C)(C)C)[C@@H](C(F)(F)F)C1</smiles><smiles>CCOC1=CC[C@@H](C(F)(F)F)N(S(=O)(=O)C(C)(C)C)C1</smiles><smiles>CC(C)(C)S(=O)(=O)N1CC=CC([Se]C2CCCC2)[C@@H]1C(F)(F)F</smiles>

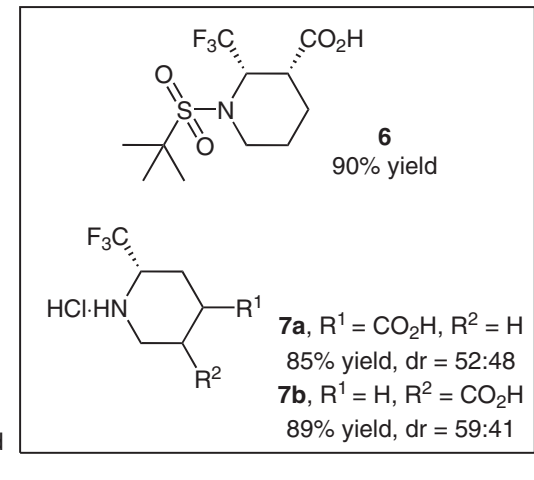

trifluoromethylpiperidinecarboxylic

acids

Significance: The physical and chemical properties of $\mathrm{N}$-heterocycles can be modified by the insertion of fluorine atoms, resulting in great advantages to medicinal chemistry and organocatalysis. In these aspects, fluorine atoms can influence the stability, conformation, basicity, and pharmacokinetic properties of $\mathrm{N}$-heterocycles (see Review below).

Review: X.-G. Hu, L. Hunter Beilstein J. Org. Chem. 2013, 9, 2696-2708.
Comment: Reported are the syntheses of the trifluoromethylated $\beta$-proline derivatives $\mathbf{2}, \mathbf{3 a}$, and $\mathbf{3 b}$ through intramolecular 5-endo-trig cyclization of the $\mathrm{N}$-homoallylic sulfinylamine $\mathbf{1}$, and the syntheses of tetrahydropyridines $\mathbf{5}$ through a ring-closure metathesis (RCM) approach starting from diallylic substrates 4 . Because the diastereomeric mixture $\mathbf{2}$ could not be separated, the protecting group was replaced with $\mathrm{Cbz}$ to permit separation. The products were then separately saponified to give the $\mathrm{N}-\mathrm{Cbz}-\mathrm{CF}_{3}-\beta$-prolines $\mathbf{3} \mathbf{a}$ and $\mathbf{3 b}$. The Grubbs second-generation catalyst was employed in an RCM process to synthesize the tetrahydropyridines $\mathbf{5}$. Amino acids $\mathbf{6 , 7 a}$, and $\mathbf{7 b}$ were prepared from tetrahydropyridines $\mathbf{5}$ by catalytic hydrogenation/oxidative degradation under Sharpless conditions for compound $\mathbf{6}$ and by catalytic hydrogenation/cleavage of the protecting group/ester hydrolysis for compounds $\mathbf{7 a}$ and $\mathbf{7 b}$.

SYNFACTS Contributors: Victor Snieckus, Sara Gomes 